\title{
Identification of inappropiate prescribing in a Geriatric outpatient clinic using the Criteria Stopp Start
}

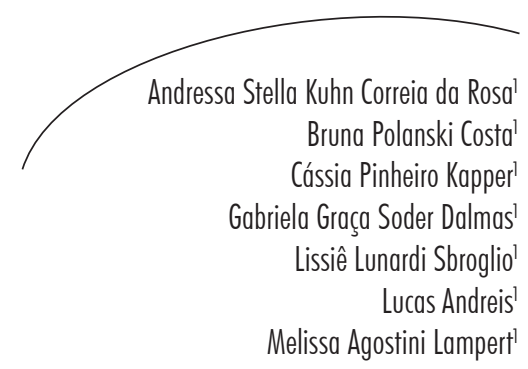

Abstract

Identified the inappropriate prescription of drugs in elderly assisted geriatric outpatient clinic in the region of Vale do Rio Pardo in Rio Grande do Sul according to the criteria of STOPP and START. Cross-sectional study of 221 elderly, based on retrospective analysis of medical records using comprehensive geriatric assessment data held in the first visit. Descriptive variables were age, sex, number of pathologies and number of medications in use. And the study variables were potentially inappropriate medications (MPI) and potentially omitted medications (MPO), according to the STOPP and START criteria. Descriptive statistics were performed with frequencies, means and standard deviations where appropriate. It was observed 157 (71\%) female patients. The average age was 75 $( \pm 8.26)$ years, $49.8 \%$ in the range of $75-84$ years. The average number of drugs was 3 $( \pm 2.27)$, with $22.63 \%$ using 5 or more medications. The average pathologies was 3.45 $( \pm 2.02)$. They identified 194 prescriptions of MPI and observed 93 MPO. The most

Keywords: Drug utilization. Health of the elderly. Polypharmacy. Ambulatory care.

\footnotetext{
Universidade de Santa Cruz do Sul, Departamento de Biologia e Farmácia, Curso de Medicina. Santa Cruz do Sul, Rio Grande do Sul, Brasil.
} 


\section{INTRODUCTION}

The combination of the growth of the elderly population and increased life expectancy means health professionals must apply great care when prescribing medication. A greater prevalence of chronic diseases, which sometimes require treatment with a combination of drugs, has increased the risk of adverse reactions, drug interactions, toxicity and reduced adherence to treatment. ${ }^{1}$ The elderly constitute $50 \%$ of multiple drug users and inadequate information and possibly harmful drug interactions are often found in their prescriptions. $^{2}$

It is therefore important to know which medications can be used, taking into consideration the characteristics of each patient and of the medications themselves, which should always be consistent with the diagnosis provided. ${ }^{3-5} \mathrm{It}$ is important to remember that a drug becomes potentially inappropriate when the risk of its use outweighs its benefit. ${ }^{6-8}$

Some studies have demonstrated that the use of a variety of medications reduces adhesion to the proposed treatment, with a greater risk of adverse reactions, drug interactions and associated morbidity and mortality. ${ }^{1,9-12}$

One attempt to reduce the occurrence of medication iatrogenesis among elderly persons involves the use of standard lists of drugs classified according to the risks and benefits generated, which are created to guide physicians when choosing treatment for their patients. Among these lists are the Beers and the STOPP and START criteria. ${ }^{6,7}$

The Beers criteria is a list of regularly updated pharmaceuticals, comprising potentially inappropriate medication (PIM) for elderly persons due to their ineffectiveness or the high risk of adverse effects. $^{13}$

The STOPP (Screening Tool of Older Person's Prescriptions) and START (Screening Tool to Alert Doctors to Right Treatment) criteria were created in 2003 with the aim of overcoming the possible deficiencies of the Beers criteria. They are composed of potentially inappropriate medications (PIMs), described by STOPP, and potential prescribing omissions (PPOs), described by START. Potential prescribing omissions are those considered essential for the success of the treatment and the preservation of the health of the elderly person. ${ }^{6,14,15}$

The presence of comorbidities in the elderly population and a greater focus on prevention in medicine has increased the need for rationality when prescribing of multiple drugs. The identification of omitted medications, in addition to those that are inappropriate, becomes a delicate task, and the use of STOPP and START criteria may be considered an auxiliary tool. It should be noted that some hypotheses should be considered when identifying the omission of a drug: prior medical suspension, problems in adherence due to cost or an adverse reaction caused by the drug. ${ }^{1,16,17}$ In other words, there are many determinants for the inadequate use of medication.

Studies have shown that the STOPP and START criteria detect a greater number of patients with potentially inappropriate prescriptions than the Beers criteria among the population studied. ${ }^{18,19}$

It has been observed that studies using the STOPP and START criteria as a guide for the identification of potential problems in the prescription of medication, which can characterize medication iatrogenesis, can be useful and contribute to improvements in the care provided to the elderly population. Brazilian studies have addressed this issue, indicating a need for further research to enable greater understanding of the health care provided to the elderly in our society. Thus, the aim of the present study was to identify the inappropriate prescription of medication to elderly persons receiving care at a geriatric outpatient clinic in a teaching center in the central region of Rio Grande do Sul. The study to sought to identify the presence of potentially inappropriate medications (PIMs) and potential prescribing omissions (PPOs), in accordance with the STOPP and START criteria. 


\section{METHOD}

A cross-sectional descriptive study of a retrospective nature was undertaken based on the analysis of the medical records of patients of a geriatric outpatient clinic in the Vale do Rio Pardo region of Rio Grande do Sul. This outpatient clinic has received elderly persons on a spontaneous demand basis since March 2011. Data collection took place at the first appointments of all the patients receiving care at the outpatient clinic, from March 2011 to March 2013, who represented the study population. Data collection was performed between April and June 2013, and the records of 264 patients were studied. The exclusion criteria were patients receiving care who were aged less than 65 years of age, as the STOPP and START criteria are valid only for people aged 65 years or more.

A form especially created for the purpose was used to collect the data from the first appointments. A comprehensive geriatric assessment (CGA) is routinely carried out during this appointment, and includes: identification data, reason for appointment, pathologies present, medications used, review of systems, living habits, family history, preventive measures, physical examination, functional evaluation, list of problems and plans. The data collection instrument was created from the CGA, and comprised: age, gender, number of pathologies and number of medications used, which were considered the descriptive variables. The PIMs and PPOs, which were considered the study variables, were defined based on the first version of the STOPP and START criteria which considers 65 PIM indicators (STOP) and $22 \mathrm{PPO}$ indicators (START). ${ }^{15}$

A PIM was considered any medication which represented an increased risk for the elderly person developing adverse effects, when there is another medication with greater effectiveness for the prescription. A PPO was considered the omission of a drug considered essential for the treatment of the elderly person. ${ }^{15-17}$

The medications were analyzed by the geriatrician responsible for the clinic and by trainees under his supervision, based on these indicators. First, the presence or absence of a relationship between the pathology present and the medications was observed, with the medications divided into systems and classes. Subsequently, the medications were identified as PIMs or PPOs.

After the completion of the data collection instrument, following prior training, the data was entered in a spreadsheet. Descriptive statistics were subsequently performed, verifying the mean, standard deviation and frequencies where appropriate. The realization of the present study followed the ethical principles of Conselho Nacional de Saúde (the Brazilian National Health Council) (CNS) Resolution 466/12 which governs research with human beings in Brazil. Each patient receiving care signed a Free and Informed Consent Form. The study was part of the Promotion of Healthy Ageing: continuous monitoring of chronic illnesses project, approved by the Ethics Committee of the Universidade de Santa Cruz do Sul.

\section{RESULTS}

Of 264 patients, 43 were excluded as were younger than 65 years. Of the 221 patients analyzed, $157(71 \%)$ were female. The mean age of the patients was 75 ( \pm 8.26$)$ years, of whom $49.8 \%$ were in the $75-84$ age range. The mean number of medications per patient was $3( \pm 2.77)$ with $22.63 \%$ of patients using five or more medications. The mean number of illnesses per patient was $3.45( \pm 2.02)$.

In terms of the inappropriate prescription of medications, 194 prescriptions with PIMs were identified, as listed in table 1, and 93 PPOs were found, as described in table 2 . 
Table 1. Potentially inappropriate medications (PIMs) according to STOPP criteria. Santa Cruz do Sul, Rio Grande do Sul, 2015.

\begin{tabular}{|c|c|c|}
\hline Classes & $\mathrm{n}$ & $\%$ \\
\hline Cardiovascular system* & 68 & $30.80 \%$ \\
\hline Loop diuretic & 1 & $0.50 \%$ \\
\hline Thiazide diuretic & 2 & $0.90 \%$ \\
\hline Non-cardioselective beta blocker & 19 & $8.60 \%$ \\
\hline Calcium channel blockers & 2 & $0.90 \%$ \\
\hline Acetylsalicylic acid & 17 & $7.70 \%$ \\
\hline Respiratory system & 5 & $2.30 \%$ \\
\hline Theophylline & 2 & $0.90 \%$ \\
\hline Systemic corticosteroids & 1 & $0.50 \%$ \\
\hline Nebulized ipratropium & 0 & $0 \%$ \\
\hline Musculoskeletal system $\dagger$ & 28 & $12.70 \%$ \\
\hline Nonsteroidal anti-inflammatory drugs $\ddagger$ & 19 & $8.60 \%$ \\
\hline Long-term corticosteroid & 3 & $1.40 \%$ \\
\hline Gastrointestinal system $\int$ & 21 & $9.50 \%$ \\
\hline Prochlorperazine or metoclopramide with Parkinsonism & 1 & $0.50 \%$ \\
\hline Proton pump inhibitor & 13 & $5.90 \%$ \\
\hline Anticholinergic/antispasmodic & 1 & $0.50 \%$ \\
\hline Central nervous system & 54 & $24.40 \%$ \\
\hline Tricyclic antidepressants & 6 & $2.70 \%$ \\
\hline Benzodiazepine & 22 & $10 \%$ \\
\hline Neuroleptic & 6 & $2.70 \%$ \\
\hline Phenothiazines & 0 & $0 \%$ \\
\hline Anticholinergics & 1 & $0.50 \%$ \\
\hline Selective serotonin reuptake inhibitors $€$ & 2 & $0.90 \%$ \\
\hline Endocrine system & 17 & $7.70 \%$ \\
\hline Glibenclamide or chlorpropamide & 9 & $4.10 \%$ \\
\hline Beta blockers & 0 & $0 \%$ \\
\hline Estrogens & 0 & $0 \%$ \\
\hline Estrogen without progestin & 1 & $0.50 \%$ \\
\hline
\end{tabular}

Developed by authors using study data; * No patients used digoxin, warfarin, clopidogrel or dipyridamole; $†$ No patients used colchicine or warfarin and NSAIDs in combination; $\ddagger$ Non-steroid anti-inflammatory drugs; $₫$ No patient used diphenoxylate, loperamide or codeine phosphate; $£$ Selective serotonin reuptake inhibitor; +One patient used PIM for the urogenital system - alpha-blocker. 
Table 2. Potential prescription omissions (PPOs), according to START criteria. Santa Cruz do Sul, Rio Grande do Sul, 2015.

\begin{tabular}{|c|c|c|}
\hline \multirow{2}{*}{ Classes } & \multicolumn{2}{|c|}{ Potential prescription omissions } \\
\hline & $\mathrm{n}$ & $\%$ \\
\hline Cardiovascular system & 44 & $25.40 \%$ \\
\hline Warfarin & 0 & $0 \%$ \\
\hline Acetylsalicylic acid & 14 & $6.30 \%$ \\
\hline Clopidogrel & 0 & $0 \%$ \\
\hline Antihypertensive therapy & 15 & $6.70 \%$ \\
\hline Statin & 9 & $4 \%$ \\
\hline Angiotensin converting enzyme inhibitor* & 21 & $9.50 \%$ \\
\hline Beta-blocker & 1 & $0.45 \%$ \\
\hline Respiratory System $†$ & 2 & $0.90 \%$ \\
\hline Beta-agonist inhaler & 2 & $0.90 \%$ \\
\hline Anticholinergic & 0 & $0 \%$ \\
\hline Corticosteroid inhaler & 0 & $0 \%$ \\
\hline Home based oxygen & 0 & $0 \%$ \\
\hline Musculoskeletal system & 21 & $9.50 \%$ \\
\hline Antirheumatic & 1 & $0.45 \%$ \\
\hline Misphosphonates & 0 & $0 \%$ \\
\hline Calcium + vitamin D & 20 & $9 \%$ \\
\hline Gastrointestinal system & 4 & $1.80 \%$ \\
\hline Proton pump inhibitor & 4 & $1.80 \%$ \\
\hline Fibers & 0 & $0 \%$ \\
\hline Central nervous system & 9 & $4 \%$ \\
\hline Levodopa & 0 & $0 \%$ \\
\hline Antidepressants & 9 & $4 \%$ \\
\hline Endocrine system & 13 & $5.80 \%$ \\
\hline Metformin & 4 & $1.80 \%$ \\
\hline Angiotensin converting enzyme inhibitor & 1 & $0.45 \%$ \\
\hline Angiotensin receptor blocker II $\ddagger$ & 0 & $0 \%$ \\
\hline Antiplatelet therapy & 11 & $4.90 \%$ \\
\hline Statins & 2 & $0.90 \%$ \\
\hline
\end{tabular}

Developed by authors using study data; *ACEI: Angiotensin Converting Enzyme Inhibitor; †The omission of anticholinergic agents, inhaled corticosteroids and home oxygen was not observed in the population studied; $\ddagger$ Angiotensin Receptor Blocker; + There were no PPOs relating to the urogenital system. 
The majority of PIMs (table 1) were in relation to the cardiovascular system. Of these, the most commonly used were non-cardioselective beta blockers and acetylsalicylic acid. The use of PIMs for the central nervous system (CNS) was also significant, with benzodiazepines standing out. The most frequently used PIMs for the musculoskeletal system were nonsteroidal antiinflammatory drugs (NSAIDs).

In terms of PPOs (Table 2), medications related to the cardiovascular system were also a significant presence, especially the omission of the prescription of acetylsalicylic acid and angiotensin converting enzyme inhibitors. There were also PPOs for medicines of the musculoskeletal system and the omission of the prescription of calcium and vitamin $\mathrm{D}$.

\section{DISCUSSION}

The majority of the sample of the present study was female $(71 \%)$. This finding was expected as women experience greater longevity in Brazil than men, due to lower female mortality. ${ }^{14}$ This finding was also observed in other studies using the STOPP and START criteria. ${ }^{8,20,21}$

Around half the patients (49.8\%) were aged between $75-84$ years, which reflects a national and global tendency of increasing life expectancy. The sample of a study by Periquito (2014) included ages from 67 to 97 years, with a mean age of 84.81 years. Such findings were higher than those of the present study, perhaps because the study was carried out in Portugal, a country with a greater life expectancy. ${ }^{8}$

The mean number of medications used by elderly persons was $3 \pm 2.77$ per patient, with $22.63 \%$ of individuals using five or more medications, indicating a significant prevalence of polymedication in the sample studied, a finding shared by other Brazilian studies. ${ }^{21,22}$ It is worth noting that polymedication is considered the use of five of more medications, but also the use of medications without genuine need. ${ }^{2,3}$
When the STOPP criteria were applied, it was found that the most frequently used PIMs were taken for cardiovascular disorders $(30.8 \%)$, corroborating the results of other studies. ${ }^{14,21}$ The prescribing of non-cardioselective beta blockers $(8.6 \%)$ and acetylsalicylic acid (7.7\%) was especially notable. One of the possible reasons for this is the unavailability, or the limited availability, of cardioselective beta blockers through the Sistema Único de Saúde (the Brazilian National Health Service), as well as a need to review the prescriptions of elderly persons, for whom acetylsalicylic acid should only be recommended as a primary and secondary intervention when the benefits for the individual outweigh the risks. ${ }^{23,}{ }^{24} \mathrm{~A}$ study that evaluated the medication consumption of elderly patients also found that the main drug used was acetylsalicylic acid. ${ }^{2}$

The second most commonly used PIMs were those that acted against the central nervous system (24.4\%). This was also found by another study, which revealed that the pharmaceuticals most frequently used by the elderly population were those for the central nervous and cardiovascular systems. ${ }^{8,23}$ In the present study benzodiazepines were the most commonly misused medications, representing 10\%, while selective serotonin reuptake inhibitors were used by $0.9 \%$ of patients. Benzodiazepines, available since 1960, are psychoactive drugs used to treat anxiety and sleep disorders. The inappropriate use of these medications demonstrates a lack of information about their action and collateral effects, as well as the lack of a correct diagnostic for their use. ${ }^{25}$ It is well known that selective serotonin reuptake inhibitors have many side effects such as nausea, vomiting, diarrhea, insomnia, anxiety, agitation and sexual dysfunction among others, which may be the reason for the reduced prescription of these drugs, which are considered potentially inappropriate for use with elderly persons. ${ }^{26}$

Medications for the skeletal system were frequently used inappropriately, with $12.7 \%$ of the sample taking such drugs. Nonsteroidal anti-inflammatory drugs (NSAIDs) were the most frequently used (8.6\%). Other studies have 
corroborated this finding. ${ }^{27}$ Control of the use of this drug remains precarious, as a prescription is not required for its acquisition. While selfmedication is always discouraged, it is even more dangerous in relation to these medications, as it is associated with a high incidence of cardiovascular and thromboembolic events in chronic medication users. NSAIDs can also induce acute kidney injury (AKI). It can also, through more rarely, result in lung problems such as bronchospasm (in individuals sensitive to aspirin) and pulmonary infiltration with eosinophilia.

The present study identified 93 omissions of medication, which was similar to the findings of another study, in which 90 omitted medications were detected. ${ }^{5}$

The prescription omissions detected were mainly in relation to medications for the cardiovascular system. This finding corroborates the thesis of Borges and Verdorn, ${ }^{14,16}$ while differing from the results of the study by Periquito, ${ }^{8}$ in which the most frequent medication omissions were related to the endocrine system, followed by the musculoskeletal system. The incidence of hypertension increases with age, with lifestyle changes recommended as method for its control. When these measures are insufficient, additional pharmacological therapy is employed. There were a total of $15(6.7 \%)$ omissions of the prescription of antihypertensive medications. The most frequent PPO was for ACE (Angiotensin Converting Enzyme) inhibitors, totaling 21 patients. Other studies have found that statin drugs feature more frequently as PPOs. ${ }^{8,14}$ In addition to ACE inhibitors, another PPO observed was acetylsalicylic acid. The use of acetylsalicylic acid has produced controversial results in different studies, although it continues to be used as an important antiplatelet, preventing thrombus formation and possible ischemia. The use of angiotensin converting enzyme (ACE) inhibitors is recommended by the START criteria as, by lowering blood pressure, these drugs prevent the appearance of very common diseases such as heart failure, and delay the progression of retinopathy and diabetic nephropathy. ${ }^{28}$

The most frequently omitted medications for the musculoskeletal system were calcium and vitamin $\mathrm{D}$, with 20 omissions, similar to that found in other studies. ${ }^{8,14}$ Supplementation with these compounds is very important, as it is difficult for the required amount of vitamin $\mathrm{D}$ to be obtained through the diet. However, calcium supplementation by capsules may be linked to increased cardiovascular risk. Ideally, calcium and vitamin $\mathrm{D}$ are acquired through diet and exposure to the sun, and should be supplemented only when insufficient amounts are received in these ways. ${ }^{29}$

From the PIMs and PPOs described, therefore, it was observed that the sample of elderly persons is exposed to inappropriate medication prescription, with a potential risk of increased morbidity and mortality associated with the use of PIMs and the loss of potential benefits due to PPOs.

The present study has some limitations. The first is the use of a cross-sectional delineation, which does not allow a temporal relationship to be established between the inappropriate prescription of medications and the presence of adverse reactions and the use of health services, for example.

Another limitation is that the data refers to the period between 2011 and 2013, with the analysis of medical records that were completed in 2013. In the last three years, modifications have taken place in treatment conduct that may result in differences in the frequencies found. Furthermore, new STOPP and START criteria emerged in 2015, with a more extensive list of PIMs and PPOs, making the comparison of data with studies using this new version difficult. ${ }^{6}$

Another limitation of the present study, which should be considered for comparisons with studies based on home-based surveys, is that it deals with community-dwelling elderly persons seeking medical care in a geriatric outpatient clinic on a spontaneous basis. However, careful analysis of medical records and prescriptions, from the first appointment and based on a comprehensive geriatric assessment, helped identify the disease and comorbidity conditions that explained the prescribing or non-prescribing of medications identified as inappropriate or omitted. This characteristic allows the use of all the STOPP and START criteria, reducing restrictions on comparisons with other studies, as well as 
minimizing the possibility that the outcomes studied have been underestimated.

\section{CONCLUSION}

The results of the present study reveal a significant prevalence of the inappropriate prescription of medications and demonstrate the need for further studies that incorporate and adapt the STOPP and START criteria to different scenarios of health care for the elderly.

Therefore, additional studies are recommended that use the STOPP and START criteria as a strategy for the optimization of established pharmacological treatments, qualifying the care provided to the elderly population in question.

\section{REFERENCES}

1. Secoli SR. Polifarmácia: interações e reações adversas no uso de medicamentos por idosos. Rev Bras Enferm [Internet] 2010 [acesso em 27 de Abril de 2015];63(1):136-40. Disponível em: http:// www.scielo.br/scielo.php?script=sci_arttext\&pid $=$ S0034-71672010000100023

2. Mosegui GB, Rozenfeld S, Veras RP, Vianna CM. Avaliação da qualidade do uso de medicamentos em idosos. Rev Saúde Pública [Internet] 1999 [acesso em 27 de Abril de 2015];33(5):437-44. Disponível em: http://www.scielo.br/pdf/rsp/v33n5/0628.pdf

3. Onders G. Strategies to reduce the risk of iatrogenic illness in complex older adults. Age Ageing [Internet] 2013 [acesso em 27 de Abril de 2015];42(3):284-29. Disponível em: http://ageing.oxfordjournals.org/ content $/ 42 / 3 / 284$.short

4. Quinalha JV, Correr CJ. Instrumentos para avaliação da farmacoterapia do idoso: uma revisão. Rev Bras Geriatr Gerontol [Internet] 2010 [acesso em 27 de Abril de 2015];13(3):487-500. Disponível em: http:// www.scielo.br/pdf/rbgg/v13n3/a14v13n3.pdf

5. Varallo FR, Ambiel ISS, Nanci LO, Galduróz JCF, Mastroianni PC. Assessment of pharmacotherapeutic safety of medical prescriptions for elderly residents in a long-term care facility. Braz J Pharm Sci [Internet] 2012 [acesso em 30 de Abril de 2015];48(3):477-85. Disponível em: http://www.scielo.br/pdf/bjps/v48n3/a15v48n3.pdf

6. O'Mahony D, O'Sullivan D, Byrne S, O' Connor MN, Ryan Cristin, Gallagher P. STOPP/START criteria for potentially inappropriate prescribing in older people: version 2. Age Ageing [Internet] 2014 [acesso em 27 de Abril de 2015];45(5):213-8. Disponível em: http:// ageing.oxfordjournals.org/content/early/2014/10/16/ ageing.afu145.full.pdf + html

7. Fick DM, Cooper JW, Wade WE, Waller JL, Maclean JR, Beers MH. Updating the Beers criteria for potentially inappropriate medication use in older adults. Arch Intern Med [Internet] 2003 [acesso em 27 de Abril de 2015];163(22):2716-24. Disponível em http://www.ncbi.nlm.nih.gov/pubmed/14662625

8. Periquito CMN, Silva PC, Oliveira P, Carneiro C, Fernandes AI, Costa FA. Revisão da medicação em idosos institucionalizados: aplicação dos critérios STOPP e START. Rev Port Farmacoter [Internet] 2014 [acesso em 05 de Maio de 2015];6:211-20. Disponível em: http://comum.rcaap.pt/handle/123456789/8477

9. Rozenfeld S, Fonseca MJM, Acurcio FA. Drug utilization and polypharmacy among the elderly: a survey in Rio de Janeiro City, Brazil. Rev Panam Salud Pública [Internet] 2008 [acesso em 28 de Abril de 2015];23(1):34-43. Disponível em: http://www. scielosp.org/pdf/rpsp/v23n1/a05v23n1.pdf

10. Medeiros EFF. Intervenção Interdisciplinar enquanto estratégia para o uso racional de medicamentos em idosos. Ciênc Saúde Coletiva [Internet] 2011 [acesso em 05 Maio de 2015];16(7):3139-49. Disponível em: http://www. scielo.br/pdf/csc/v16n7/14.pdf

11. Buck MD, Atreja A, Brunker CP, Jain A, Suh TT, Palmer RM, et al. Potentially Inappropriate medication prescribing in outpatient practices: prevalence and patient characteristics based on electronic health records. Am J Geriatr Pharmacother [Internet] 2009 [acesso em 28 de Abril de 2015];7(2):84-92. Disponível em: http://www.ncbi. nlm.nih.gov/pubmed/19447361

12. Hajjar ER, Cafiero AC, Hanlon JT. Polypharmacy in elderly patients. Am J Geriatr Pharmacother [Internet] 2007 [acesso em 05 de Maio de 2015];5(4):345-51. Disponível em: http://www.ncbi. nlm.nih.gov/pubmed/18179993

13. American Geriatrics Society. American Geriatrics Society 2015 Updated Beers Criteria for potentially inappropriate medication use in older adults. J Am Geriatr Soc 2015;63(11):2227-46.

14. Verdoorn S, Kwint HF, Faber A, Gussekloo J, Bouvy ML. Majority of drug-related problems identified during medication review are not associated with STOPP/START criteria. Eur J Clin Pharmacol 2015;71:1255-62. 
15. O’Mahony D, Gallangher P, Ryan C, Byrne S, Hamilton H, Barry P, et al. STOPP \& START criteria: a new approach to detecting potentially inappropriate prescribing in old age. Eur Geriatr Med [Internet] 2010 [acesso em 27 de abril de 2015]1(1):45-51. Disponível em: http://www.europeangeriaticmedicine.com/ article/S1878-7649(10)00011-2/fulltext

16. Borges EP. Omissão de prescrição de fármacos na população idosa da Beira Interior [Dissertação na internet]. Portugal: Universidade da Beira Interior; 2010 [acesso em 28 de Abril de 2015]. Disponível em: http://hdl.handle.net/10400.6/754

17. Abrantes MFB. Seguimento farmacoterapêutico em idosos polimedicados [Dissertação na Internet]. Porto: Universidade de Fernando Pessoa; 2013 [acesso em 22 de Maio de 2015]. Disponível em: http://bdigital.ufp.pt/bitstream/10284/4102/1/ Seguimento $\% 20$ farmacoterapêutico $\% 20 \mathrm{em} \% 20$ idosos $\% 20$ polimedicados-signed.pdf

18. Ubeda A, Ferrándiz ML, Maicas N, Gómez C, Bonet $\mathrm{M}$, Peris JE. Potentially inappropriate prescribing in institutionalised older patients in Spain: the STOPPSTART criteria compared with the Beers criteria. Pharm Pract [Internet] 2012 [acesso em 27 de Abril de 2015];10(2):83-91. Disponível em: http://scielo. isciii.es/pdf/pharmacin/v10n2/original3.pdf

19. Taylor BH. Application of the STOPP/START criteria: a systematic review of the prevalence of potentially inappropriate prescribing in older adults, and evidence of clinical humanistic and economic impact. J Clin Pharm Ther [Internet] 2013 [acesso em 28 de Abril de 2015];38(5):360-72: Disponível em: http://onlinelibrary. wiley.com/doi/10.1111/jcpt.12059/full

20. Camarano AA. Mulher idosa: suporte familiar ou agente de mudança? Estud Av [Internet] 2003 [acesso em 09 de Junho de 2015];17(49):35-63. Disponível em: http://www.scielo.br/scielo.php?script=sci_ arttext\&pid=S0103-40142003000300004\&lng=en\&tl ng=pt. 10.1590/S0103-40142003000300004

21. Martins GA, Acurcio FA, Franceschini SCC, Priore SE, Ribeiro AQ. Uso de medicamentos potencialmente inadequados entre idosos do Município de Viçosa, Minas Gerais, Brasil: um inquérito de base populacional. Cad Saúde Pública [Internet] 2015 [acesso em 15 Jul. 2016];31(11):2401-12. Disponível em: http://www.scielo.br/scielo.php?script=sci_ arttext\&pid=S0102-311X2015001102401\&lng=en. http://dx.doi.org/10.1590/0102-311X00128214
22. Araújo CMC, Magalhães SMS, Chaimowicz F. Uso de medicamentos inadequados e polifarmácia entre idosos do Programa Saúde da Família. Lat Am J Pharm 2010;29(2):178-84.

23. De Santis SLPT. Polimedicação e medicação potencialmente inapropriada no idoso: estudo descritivo de base populacional em cuidados de saúde primário [dissertação na Internet]. Coimbra: Universidade de Coimbra; 2009 [acesso em 28 de Abril de 2015]. Disponível em: https://eg.sib.uc.pt/handle/10316/14808

24. Patrono C. Aspirin resistance: definition, mechanisms and clinical read-outs. J Thromb Haemost [Internet] 2003 [acesso em 02 Junho de 2015];1(8):1710-3. Disponível em: http://onlinelibrary.wiley.com/ doi/10.1046/j.1538-7836.2003.00284.x/full

25. Firmino KF, Abreu MHNG, Perini E, Magalhães SMS. Fatores associados ao uso de benzodiazepínicos no serviço municipal de saúde da cidade de Coronel Fabriciano, Minas Gerais, Brasil. Cad Saúde Pública [Internet] 2011 [acesso em 02 de Junho de 2015];27(6):1223-32. Disponível em: http://www. scielo.br/pdf/csp/v27n6/19.pdf

26. Moreno RA, Moreno DH, Soares MBM. Psicofarmacologia de antidepressivos. Rev Bras Psiquiatr [Internet] 1999 [acesso em 02 de Junho de 2015];21(1):24-40. Disponível em: http://www. scielo.br/scielo.php?script $=$ sci_arttext\&pid=S151644461999000500006\&lng=en

27. Rozenfeld S. Prevalência, fatores associados e mau uso de medicamentos entre os idosos: uma revisão. Cad Saúde Pública [Internet] 2003 [acesso em 02 de Junho de 2015];19(3):717-24. Disponível em: http://www.scielosp.org/scielo.php?script=sci_ arttext\&pid=S0102-311X2003000300004\&lng=en

28. Tavares JR. Antiplaquetários na Síndrome Coronariana Aguda. Rev Soc Cardiol Estado de São Paulo [Internet] 2007 [acesso em 02 de Junho de 2015]; 17:271-88. Disponível em: http://bases.bireme. br/cgi-bin/wxislind.exe/iah/online/?IsisScript=iah/ iah.xis\&src $=$ google \&base $=$ LILACS\&lang $=$ p\&next Ac tion $=\operatorname{lnk} \&$ exprSearch $=471895 \&$ indexSearch $=$ ID

29. Reid IR. Cardiovascular effects of calcium supplements. Nutrients [Internet] 2013 [acesso em 02 de Junho de 2015];5(7):2522-9. Disponível em: http:// www.ncbi.nlm.nih.gov/pmc/articles/PMC3738985/ pdf/nutrients-05-02522.pdf 